\title{
Neuter gender in the languages of Aru
}

\author{
ANTOINETTE SCHAPPER
}

\begin{abstract}
This paper examines gender agreement in three little-known languages of the Aru Islands and places them within the larger pattern of "neuter gender" in eastern Indonesia. For each language, I look first at the variety of agreement targets that are controlled by gendered nouns. Secondly, I look at the semantics of nouns that control agreement. I show that whilst having a strongly semantic base involving animacy, gender in Aru languages is a grammatical category in which many nouns denoting certain types of entities that lack discernable biological animacy are assigned to the same gender as that of animate referents. I conclude by considering the system of gender in proto-Aru.
\end{abstract}

KEYWORDS

Nominal classification, neuter gender, Aru, Austronesian languages.

\section{INTRODUCTION ${ }^{1}$}

Together eastern Indonesia and East Timor constitute a vast and diverse region in which many languages of different genetic affiliations and varied typological profiles reside. In his work Hein Steinhauer has been key in bringing to light many features of languages from across this region. One of the most notable findings is presented in Steinhauer (1985) where Biak [ISO 639-3: bhw] ${ }^{2}$, an Austronesian language of Cenderawasih Bay, is first shown to contravene the following of Greenberg's (1963) Universals:

1 This research was supported by grant "The Aru Languages Documentation Project" (Projekt 86 277) funded by the DoBeS programme of the Volkswagen Foundation. Thanks go to the many colleagues who have assisted with and participated in the project, in particular, Benjamin Daigle, Nikolaus Himmelmann, Jock Hughes, Rick Nivens, Richard Olson, Jakub Pszczolka, David de Winne, and Emilie T.B. Wellfelt. All errors are of course my own.

2 Throughout this paper, languages are cited with their ISO 639-3 codes. These codes are unique three-letter identifiers with comprehensive coverage of the world's languages.

ANTOINETTE SCHAPPER took her PhD degree at the Australian National University with a grammar of the Papuan language, Bunaq spoken in central Timor. She is currently leading the DoBeS-sponsored "The Aru Languages Documentation Project" at the University of Cologne, and is conducting a post-doctoral project on the lexico-semantic evolution of the Papuan languages of the Timor-Alor-Pantar family at the KITLV in Leiden, The Netherlands. Antoinette Schapper may be contacted at: a_schapper@hotmail.com.

(C) 2015 Faculty of Humanities, University of Indonesia

DOI: 10.17510/wjhi.v16i1.364 
Universal 37. A language never has more gender categories in nonsingular numbers than in the singular.

Universal 45. If there are any gender distinctions in the plural of the pronoun, there are some gender distinctions in the singular also.

Steinhauer (1985) shows that Biak possesses a gender distinction between animates and inanimates marked in the 3rd person plural but not the 3rd person singular of personal pronouns, verbal agreement prefixes, alienable possessive pronouns and demonstratives (see also Van Heuvel 2006).

Since Steinhauer (1985) our knowledge of the languages of the region has increased considerably and we now know of several languages which violate these proposed universals (for example, Dusner [ISO 639-3: dsn], Dalrymple and Mofu 2012; Windesi-Wandamen [ISO 639-3: wad], Gasser 2015; Nuaulu [ISO 639-3: nxl], Bolton 1990). ${ }^{3}$ It has also become clear that the gender distinctions we find in these languages are part of a broader areal pattern in which a "neuter gender" distinction is made in the 3rd person. In Schapper (2010), I identify many eastern Indonesian languages as having a "neuter" versus "non-neuter" gender distinction involving a binary division of referents into classes according to their position on the animacy hierarchy, with "neuter" defining a class of referents lower on the animacy hierarchy and "non-neuter" one higher up, much as in Biak.

At the same time, closer investigation of these systems has shown that they are often grammatical genders. Reference to the animacy hierarchy and the use of terms such as (in)animate and (non-)human in describing the genders gives the impression that gender assignment in these eastern Indonesian languages is entirely semantic. Yet, this is not the case. In Biak, for instance, animate agreement is taken by many nouns with inanimate referents such as alcoholic drinks, metals and items made from them, vegetable or animal products which are small in size and typically occur in quantities (Van Heuvel 2006: 101-102).

In this paper, I revisit the topic of eastern Indonesian neuter gender systems. Thus far treatment of the different systems, both in individual language descriptions and in comparative studies, has focussed on the agreement targets which nouns of "neuter" and "non-neuter" gender control respectively; little attention has been given to the actual assignment of nouns to genders beyond the broadest semantic labels. This paper looks at neuter gender assignment in three little-known languages of the Aru archipelago in eastern Indonesia. Until recently these languages had received little academic attention and the details of their agreement systems and gender assignment are only beginning to emerge now. I show that, similar to Biak, whilst having a strongly semantic base involving animacy, gender in Aru languages is a grammatical category in which many nouns denoting certain types of entities 
that lack discernable semantic animacy are assigned to the same gender as that of animate referents.

This paper is structured as follows. In Section 2, I introduce the languages of Aru and briefly outline previous work on them. In Section 3, I look at the agreement systems and gender assignment of nouns in three Aru languages, Ujir, Kola, and Dobel. In Section 4, I conclude by comparing the different patterns of exceptional gender assignment in the Aru languages discussed and the occurence of gender in proto-Aru, their common ancestor.

\section{THE LANGUAGES OF ARU}

Situated at the far eastern edge of Indonesian territory, the Aru Islands form a tightly knit archipelago of over a hundred islands in the Arafura Sea between New Guinea and Australia (Map 1).

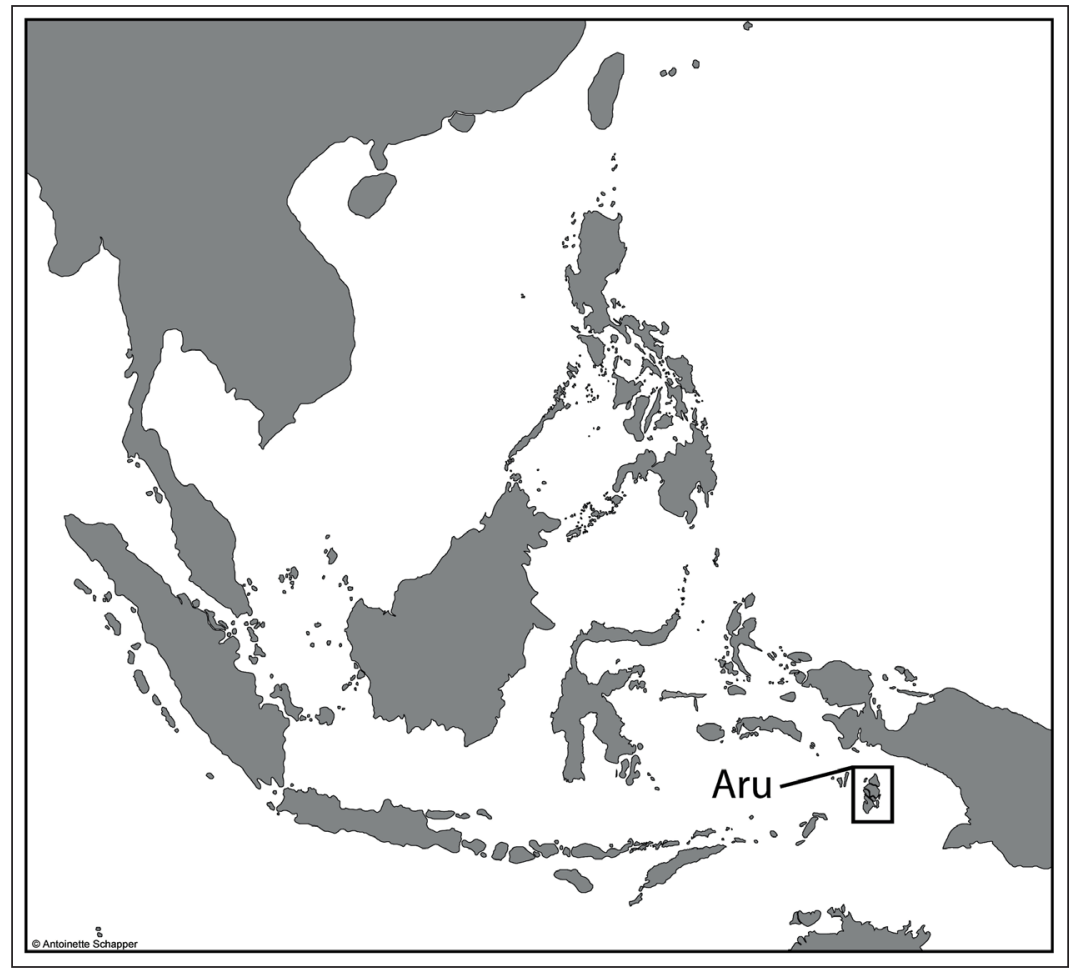

Map 1. The Aru Islands in Southeast Asia.

There are fourteen languages spread across the Aru archipelago (Map 2). All belong to the Austronesian family. They constitute their own low-level sub-group, though the internal constituency of the subgroup is unclear (for instance, Collins 1982 and Hughes 1987 come to different conclusions about the sub-grouping of the Aru languages). The Aru sub-group has been tentatively assigned to the higher Central Malayo-Polynesian (CMP) subgroup (Blust 1993), but the existence of this group is far from secure (Donohue and Grimes 2008; Schapper 2011). 


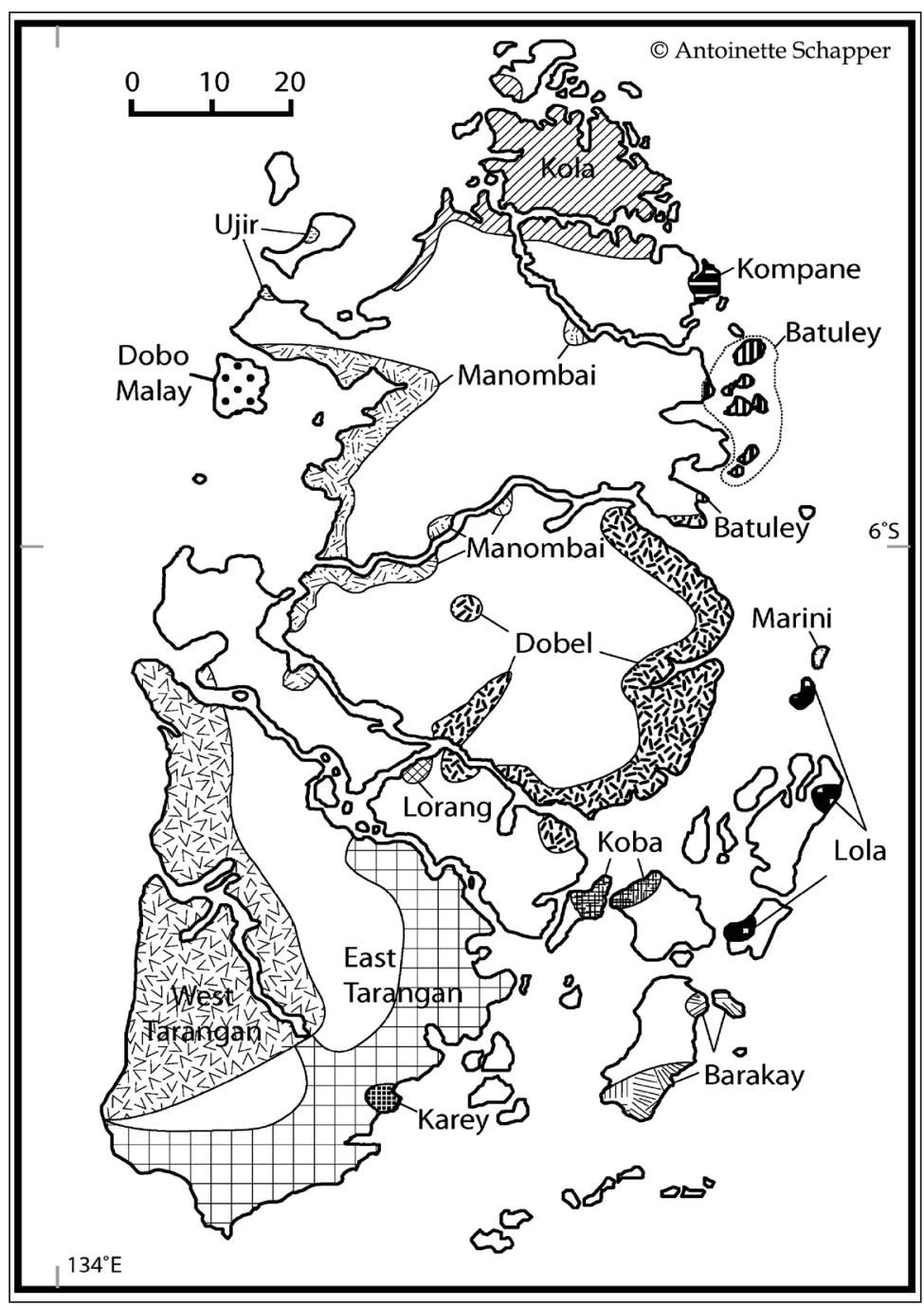

Map 2. The languages of Aru (based on Lewis et al. 2014).

So little is known about the Aru languages that Blust (2009) in his 800-page handbook detailing the state of the art in Austronesian linguistics does not discuss them at all. Teams from the Summer Institute of Linguistics (SIL) have been working with speakers of Aru languages since the 1980s. Their work has resulted in several publications on three languages by themselves and others using their materials: Dobel (J. Hughes and K. Hughes 1989; Hughes 1995, 2000; Blust 2014), Kola (Y. Takata 1992; T. Takata and Y. Takata 1991a-b, 1992a-b; De Winne 2013), and West Tarangan (Nivens 1992, 1993, 2002). At the time of writing, there is, however, no thorough linguistic description or widely available documentation of any language of Aru.

\section{GENDER IN ARU}

Aru languages typically have a gender distinction marked in the following 
domains: on verb agreement, on numerals, and on demonstratives. The basic gender distinction is one of ANIMATE versus INANIMATE. ${ }^{4}$ The systems in all languages have a strong semantic basis, that is, in most cases it is sufficient to know the meaning of a noun in order to determine its gender. However, in each language the basic semantic pattern is complicated by the inclusion of entities that lack discernable semantic animacy in the ANIMATE gender. The patterns for assigning nouns which lack real-world animacy to the ANIMATE class differ between languages, as do the agreements which they control. In the following sub-sections we will concentrate on the differences between three languages, Ujir (Section 3.1), Kola (Section 3.2), and Dobel (Section 3.3).

\subsection{UJIR}

Ujir [ISO 639-3: udj] is a language of North-West Aru traditionally spoken in two villages, Ujir and Samang. Today, Ujir is highly endangered, only being spoken by a very small percentage of inhabitants of the villages. The data used in this section come from my own fieldwork on Ujir, the recordings from which are being made available at The Language Archive (https:/ / corpus1.mpi.nl/).

\subsubsection{LOCUS OF GENDER MARKING}

Ujir subject verb agreement is of two kinds, active verb prefixes and stative verb enclitics. 3rd person forms of both are given in (1). Of these, only the stative verb enclitics mark the ANIMATE-INANIMATE gender distinction. Active verb prefixes are invariably used with subjects of both genders.

Ujir 3rd person verb agreement

(1) a. Active verb prefixes

$$
\text { 3SG } \quad a-\quad 3 \mathrm{PL} \quad d a-
$$

b. Stative verb enclitics

$$
\begin{aligned}
\text { 3SG.AN }=n a & \text { 3PL.AN }=s i \\
& \text { 3PL.INAN }=d i
\end{aligned}
$$

On stative verbs distinct agreement forms for the two genders are limited to the plural. Compare the agreement forms on the stative verb bangi 'big' in (2) when it is the predicate to the ANIMATE noun tamata 'person' (2a) versus the INANIMATE noun juma 'house' (2b).

Ujir 3rd plural stative agreement

(2) a. ANIMATE subject

Tamata bangi $=$ si.

person big=3PL.AN

'The people are big.'

$4 \quad$ Throughout this paper, small caps ANIMATE and INANIMATE are used in reference to the grammatical classification of nouns in Aru languages, while lower case "animate" and "inanimate" are used in reference to the real-world, semantic animacy of referents. 
b. INANIMATE subject

Juma bangi=di.

house big=3PL.INAN

'The houses are big.'

In the singular, subject nouns of INANIMATE gender do not take agreement on stative verbs, while ANIMATE subjects take $=n a$. This contrast in marking is illustrated in (3) with the stative verb joi 'cold'.

Ujir 3rd singular stative agreement

(3) a. ANIMATE subject

Oba leltu joi=na.

child still cold $=3$ sG.AN

'The child is still cold.'

b. INANIMATE subject

Waai leltu joi.

water still cold

'The water is still cold.'

Ujir numerals also inflect to agree with the head noun of the NP in which they occur. The 3rd person inflections occurring on numerals are identical to the agreement enclitics on stative verbs (4). The 3rd person plural INANIMATE inflection $=d i$ found on stative verbs, however, does not occur on numerals.

Ujir 3rd person numeral inflection

(4) 3SG.AN $=n a \quad 3 P L . A N=s i$

Numerals do not agree with nouns of INANIMATE gender. This is seen in comparing the (a) and (b) examples in (5) and (6). The enclitics are used for agreement with ANIMATE nouns: $=n a$ occurs on the numeral 'one' $(5 b)$, while $=$ si occurs on all other numerals (6b).

a. tul set

bone one

'one bone'

(6) a. tul dubu

bone six

'six bones' b. woytaw set $=\underline{n a}$

bird one $=3$ sG.AN

'one bird'

b. woytaw dubu=si

bird six=3PL.AN

'six birds'

The Ujir indefinite article, which historically was the numeral 'one' but has been replaced by set, shows a similar agreement pattern: sia is the INANIMATE form, while sina is the ANIMATE form, as illustrated in (7). 
(7)
a. juma sia
b. koday
$\underline{\sin a}$
house
INDEF.INAN
'a house'
Woman INDEF.AN
'a woman'

Ujir demonstratives are also marked for gender. In contrast to stative verbs, on demonstratives gender is distinguished in the singular but not in the plural (8).

\begin{tabular}{|c|c|c|c|}
\hline \multicolumn{4}{|c|}{ Ujir demonstratives $^{5}$} \\
\hline & \multicolumn{2}{|c|}{ SG } & PL \\
\hline & AN & INAN & \\
\hline THIS & $n a$ & $a$ & -- \\
\hline THIS & nakin & akin & nasin \\
\hline THAT & nel & el & nes \\
\hline
\end{tabular}

The ANIMATE-INANIMATE contrast on demonstratives is illustrated with the distal "THAT" demonstrative in (9a) and (9b).
a. Sia bisa a-inaw [tamata nel] $\mathrm{NP}$ a-ludi
who can 3sG-cause person THAT.AN 3sG-remove
na= クum?
3sG.POSS $=$ cloth
'Who can make that person remove his cloth?'
b. M-dasil [tel ell $] \mathrm{NP}$.
2sG-release rope THAT.INAN
'Undo that rope.'

\subsubsection{SEMANTICS OF GENDER ASSIGNMENT}

Thus far the examples we have presented of Ujir gender agreement have used nouns whose grammatical gender coincides with the biological status of their referents. That is, we have only seen examples in which ANIMATE nouns refer to real-world animates, and INANIMATE nouns to real-world inanimates. At this stage relatively little is known about the principles of classification in Ujir and the observations that follow are preliminary.

The nouns with inanimate referents known to be classified ANIMATE include common material goods used in the home and garden, such as the high frequency sou 'plate', soru 'axe', tana 'pot' and jujur 'spoon'. Their ANIMATE agreement is illustrated in the examples in (10). 
(10) a. Sou nel aywaku=na.

plate THAT.AN dirty=3sG.AN

'That plate is dirty.'

b. Soru nel din $=\underline{n a}$

axe THAT.AN heavy=3sG.AN

'That axe is heavy.'

c. Tana $\underline{n a} \quad$ esi=na

pot THIS.AN empty=3sG.AN

'That pot is empty.'

d. Lujur nel a-mina ba?

spoon THAT.AN 3sG-live where

'Where is that spoon?'

ANIMATE nouns of this type include many borrowed words, such as Malay buku 'book', suling 'flute', bal 'ball' and cangkir 'cup', illustrated in (11).

(11)

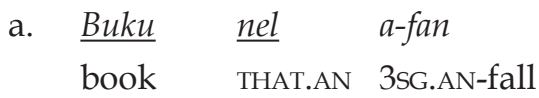
'That book fell down.'
b. Sulin nakin da-inaw= na da-paki ful.
flute THIS.AN 3PL-make=3sG.AN 3PL-use hair
'This flute is made using hair.'
c. Bola nel a-mina ba?
ring THAT.AN 3sG-located where
'Where is the ball?'

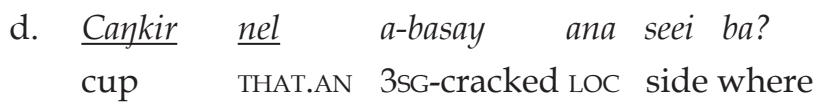
'The cup is cracked on which side?'

Nouns referring to many metal items are frequently classified as ANIMATE. Examples include taytayan 'ring', kalawarwar 'bracelet', and rubil 'spear', each illustrated in (12).
(12)
a. Taytanan nel a-mina ba? ring THAT.AN 3sG-stay where
'Where is the ring?'
b. Kalawarwar rua=si da-mina meja tuti. bracelet two $=$ AN 3PL-stay table top
'There are two bracelets on the table top.' 


$\begin{array}{llll}\text { c. } & \begin{array}{l}\text { Rubil } \\ \text { spear }\end{array} \underline{\mathrm{si}} \quad \text { dour=AN } & \text { 3PL-stay } \quad \text { table } & \text { tuti. } \\ \text { 'There are four spears on the table top.' } & \end{array}$

There are also nouns referring natural features or events classified as ANIMATE, including fat 'stone, rock', mareen 'wave' and kafkafal 'cloud, illustrated in (13).
(13) a. Tel yiri sia a-mina fat sina tuti. rope piece INDEF.INAN 3sG-stay stone INDEF.AN top 'A piece of rope is on top of a stone.'
b. Mareen lati $\underline{\underline{s i}}$ da-ma. wave three $=$ AN 3 PL-come
'There came three waves.'
c. Kafkafal nel a-mina ba? cloud THAT.AN 3sG-stay where 'Where is that cloud?'

The noun kay 'tree, wood' has flexible classification. It is classified ANIMATE where it refers to a standing tree in its entirety, but where it refers to a piece of wood it is classified INANIMATE. This classification distinction is apparent in the agreement forms taken by kay in its two appearances in (14).

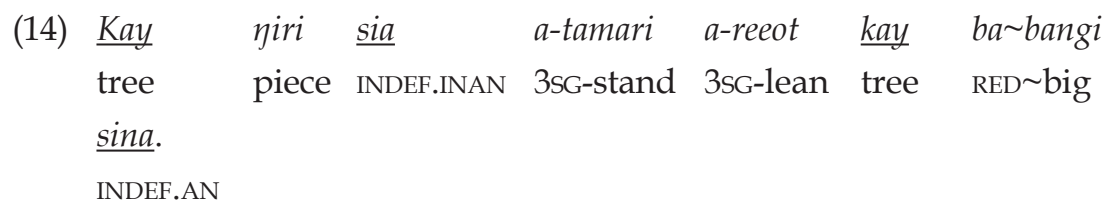

'A piece of wood stands leaning on a big tree.'

Consistent with this, all compounds involving kay and referring to plant parts are classified INANIMATE, as in (15).
(15) a. Kay fu fuay $\underline{e l} a-m i n a ~ b a ?$ tree RED fruit THAT.INAN 3sG-stay where
'Where is the fruit?'
b. Kay wiri wiri el a-mina ba? tree RED root THAT.INAN 3sG-stay where
'Where is the medicine (= root)?'

\subsection{KOLA}

Kola [ISO 639-3: kvv] is the northern most language of Aru, dominating on 
Kola Island and parts of northern and western Wokam Island. The language is vibrant with an estimated 7,000 speakers and many children among them (Lewis et al. 2014). The data used in this section is drawn from a variety of sources: the publications of the Takata SIL team (Y. Takata 1992; M. Takata and Y. Takata 1992a, 1992b), the dictionary manuscript of another SIL linguist, Richard Olson (n.d.), the Masters thesis of David de Winne (2013) using SIL materials and subsequent original fieldwork by him (also being archived at https://corpus1.mpi.nl/).

\subsection{LOCUS OF GENDER MARKING}

Kola subject verb agreement forms in the 3rd person are presented in (16). Kola active verb prefixes do not mark the ANIMATE-INANIMATE gender distinction. Kola stative verb enclitics, however, show more limited gender marking than in Ujir with no distinct, contrastive ANIMATE versus INANIMATE agreement forms being available in the singular or plural.

Kola 3rd person verb agreement

(16) a. Active verb prefixes

3SG $\quad a-3 \mathrm{PL} \quad d a-$

b. Stative verb enclitics

$$
3 \mathrm{SG} . \mathrm{AN} \quad=n i \quad 3 \mathrm{PL} \quad=y i \sim=d i
$$

Kola stative verbs agree with subject nouns of ANIMATE gender in the singular using $=n i(17 \mathrm{a})$, while INANIMATE singular subjects are not marked by any agreement form on the verb $(17 b)$.

Kola 3rd singular stative agreement

a. ANIMATE subject

$\begin{array}{lccl}\mathrm{Na} & \phi o & \text { rumau } & \text { ahlah }=\underline{n i} \\ \text { 3.POss } & \text { dog } & \text { already } & \text { big=3sG.AN } \\ \text { 'His dog is already big.' (Olson n.d.) } & \\ \text { INANIMATE subject } & \end{array}$

$\begin{array}{lll}\text { dalau } & \text { akin } & \text { ahlah. } \\ \text { house } & \text { THIS.SG.INAN } & \text { big. }\end{array}$

'This house is big.' (Olson n.d.)

Some Kola stative verbs are double marked for 3rd person singular, giving the superficial appearance of an ANIMATE-INANIMATE distinction. In the 3rd person singular disyllabic stative verbs with the shape $(\mathrm{C}) \mathrm{V}(\mathrm{C}) \mathrm{a}(\mathrm{C})$ where $\mathrm{V}$ is not /a/ have an umlaut rule whereby the /a/ vowel becomes /i/. Examples are provided in Table 1 . We see that the umlaut is not limited to the 3 rd person singular of ANIMATE or INANIMATE gender but occurs in both forms of the verbs, and does not prevent regular marking of ANIMATE gender with $=n i$ ' 3 SG.AN'. 


\begin{tabular}{|c|c|c|c|}
\hline & eta 'tall' & fulal 'lame' & kuat 'strong' \\
\hline 1sG & $e t a=\eta \dagger$ & fulal $=u \eta \dagger$ & kuat $=u \eta \dagger$ \\
\hline 2sG & eta $=k a$ & fulal $=k a$ & $k u a t=k a$ \\
\hline 3SG.INAN & $\underline{\text { eti }}$ & fulil & $\underline{\text { kuit }}$ \\
\hline 3SG.AN & $\underline{\text { eti }}=n i$ & fulil $=n i$ & $\underline{\text { kuit }}=n i$ \\
\hline 1PL.INCL & et $a=s i t a$ & fulal $=$ sita & kuat $=$ sita \\
\hline 1PL.EXCL & eta $=\mathrm{kam}$ & fulal $=\mathrm{kam}$ & kuat $=\mathrm{kam}$ \\
\hline $2 \mathrm{PL}$ & eta $=$ kem & fulal $=$ kem & kuat $=$ kem \\
\hline 3PL & eta $=y i \sim$ eta $=d i \ddagger$ & fulal $=y i$ & $k u a t=y i$ \\
\hline
\end{tabular}

† These are allomorphs appearing on vowel- and consonant-final roots respectively. ¥ This alternation is discussed further below.

Table 1. Kola stative verbs showing i-umlaut in the 3rd person singular.

In the plural Kola does not have the distinct agreement forms for the two genders as are found in Ujir. Instead, the forms $=y i$ and $=d i$ appear to be lexicalised variants of one another. That is, on the vast majority of stative verbs a 3rd person plural subject is marked with $=y i$, but on some verbs it can be marked with either $=y i$ or $=d i$ with no apparent difference in meaning. ${ }^{6}$ The stative verbs known to show this variation are given in Table 2.

\begin{tabular}{llll}
\hline Root & Gloss & 3rd plural forms & \\
\hline arker & fierce & arkeryi & arkerdi $\dagger$ \\
digil & noisy & digilyi & digildi \\
eta & tall, high & etayi & etadi \\
mila & fat & milayi & miladi \\
muwai & nauseous & - & muwaidi \\
raraf & feverish & rarafyi & rarafdi \\
reen & clever & reenyi & reendi $\dagger$ \\
sooh & dead & soohyi & soohdi \\
tare & all & tareyi & taredi \\
yooh & cold & yoohyi & yoohdi \\
\hline
\end{tabular}

† These two inflections are only attested in the Langhalau dialect of Kola.

Table 2. Kola stative verbs with $=y i$ or $=d i$ in 3 rd person plural (data drawn from Olson n.d.).

$6 \quad$ De Winne (2013: 40) finds the agreement form =di but not =yi for 3rd person plural on stative verbs in M. Takata and Y. Takata (1991). 
Kola numerals also inflect to agree with the head noun of the NP in which they occur. Table 3 presents the basic Kola numerals. We see that unlike Ujir gender marking morphemes on Kola numerals cannot be easily segmented, though an /i/ vowel is consistently associated with ANIMATE agreement forms: on consonant final INANIMATE inflections of numerals the corresponding ANIMATE forms are produced by the addition of / $i$ / finally, and; on INANIMATE inflections of numerals with final /a/, /a/ is replaced with /i/, in a process similar to the i-umlaut observed with stative verbs. Numerals 'six' and 'seven' also show irregular changes in their roots between ANIMATE and INANIMATE numeral inflections, while the ANIMATE agreement form of 'one' is marked by $n i$.

\begin{tabular}{lll}
\hline & INANIMATE & ANIMATE \\
\hline 1 & ot & otni \\
2 & rua & rui \\
3 & las & lasi \\
4 & kafa & kafi \\
5 & lima & limi \\
6 & dum & dubi \\
7 & dubam & dubabi \\
8 & kafarua & kafarui \\
9 & tera & teri \\
10 & fuh & fuhi \\
\hline
\end{tabular}

Table 3. Kola numerals (Y. Takata 1992: 52).

The different form numerals take depending on the noun they modify is illustrated with the numeral 'five' in (18).

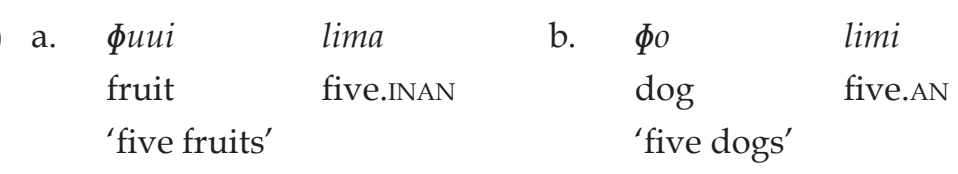

There is in fact reason to consider the numerals glossed here as INANIMATE as unmarked for gender, as in Ujir. Evidence for this comes from complex numeral expressions used for forming numbers higher than ten where only the right-most numeral agrees in animacy with the head noun it quantifies. This is seen with 'twelve' in (19): the agreement controller, wowawa 'children', is ANIMATE but of the two numerals ('ten' and 'two') used to form the complex numeral only ' $\mathrm{t} w \mathrm{w}$ ' has the expected ANIMATE form, but 'ten' takes the INANIMATE form. If the numerals used in agreement with INANIMATE nouns were really marked for INANIMATE gender we would not expect them to be able to occur in such contexts. 


$$
\begin{array}{lllll}
\text { wowawa } & k a & {[\text { fuh }} & \text { mo } & \text { rui }]_{\mathrm{NUM}} \\
\text { children } & \text { PL } & \text { ten.INAN } & \text { plus } & \text { two.AN } \\
\text { 'twelve children' (Olson n.d.) } & &
\end{array}
$$

Kola demonstratives are also marked for gender. Kola has two sets of demonstratives, those that occur independent of a head noun ("pronominal demonstratives" in 20a) and those that are dependent on a head noun ("attributive demonstratives" in 20b). Whilst pronominal demonstratives distinguish ANIMATE-INANIMATE in the singular and plural, attributive demonstratives only make the gender distinction in the singular.

Kola demonstratives (Y. Takata 1992)

(20) a. Pronominal demonstratives

SG

$\begin{array}{lllll} & \text { AN } & \text { INAN } & \text { AN } & \text { INAN } \\ \text { THIS } & (\text { ne }) \text { nan } & \text { an } & \text { ikar } & \text { ikan } \\ \text { THAT nen } & \text { en } & \text { iker } & \text { iken }\end{array}$

b. Attributive demonstratives

$\begin{array}{llll} & & \text { SG } & \text { PL } \\ & \text { AN } & \text { INAN } & \\ \text { THIS } & n a & a & k a \\ \text { THAT } & n e & e & k e\end{array}$

The ANIMATE-INANIMATE contrast on Kola demonstratives is illustrated with the distal attributive "THAT" demonstrative in (21).

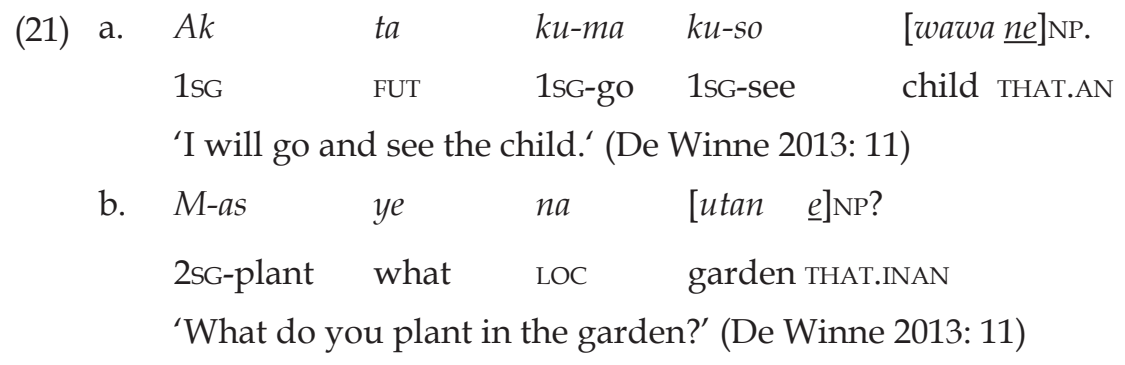

Yuko Takata's (1992) analysis of demonstratives appears to be incomplete. Olson (n.d.) gives demonstrative forms that are not found in this publication, including: ana, ena, nakin, ekin, nekin, kekin, ikakin, kakin. Whilst the gender of these items is clear, their syntax and semantics remains for future work to clarify.

\subsubsection{SEMANTICS OF GENDER ASSIGNMENT}

Gender in Kola is a grammatical category but with a strong semantic basis. Y. Takata 
(1992: 47-48) observes that ' [a]lthough most nouns may be intuitively classified either as animate or inanimate, there are some exceptions: several nouns are grammatically classified as [ANIMATE] in Kola even though they would be scientifically classified

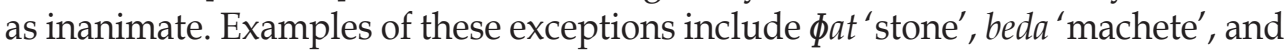
nasa $[h]$ 'basket', which are each grammatically treated as belonging to the [ANIMATE] noun class in Kola.' The examples in (22) illustrate the agreement behaviour of these ANIMATE nouns denoting inanimates.
a. $\underline{\phi a t} \underline{n a} \quad \operatorname{diin}=\underline{n i}$.
stone THIS.AN heavy=3sG.AN
'This stone is heavy.' (Olson n.d.)
b. Beda $\underline{\text { ne }}$ mayin $=\underline{n i}$.
machete THAT.AN sharp=3sG.AN
'That machete is sharp.' (Olson n.d.)
e. Nasah ne ramau yali=ni $\underline{n i}$ a-ka nuh.
basket THAT.AN already full=3sG.AN 3sG-for coconut
'That basket is already full with coconuts.' (Olson n.d.)

These classifications appear to be part of larger patterns in the language which will be discussed and exemplified further in what follows.

Many man-made items are classified as ANIMATE in Kola. De Winne (2013: 12) records the ANIMATE nouns netak 'axe' and wawauh 'sago pounder'. To this list, Olson (n.d.) adds: aldala 'gong', buk 'book', daфal 'spear', gah 'basket for betel nut', kiryaban 'mat', laya 'arrow', mahian 'hold of a ship/canoe' sabuan 'spit post', sariba 'knife', suhat 'letter', tapigih 'dish', tubal 'bowl', and wilun 'rudder'. However, the classification is not predictable; similar, though fewer, man-made items are classified INANIMATE such as: boban 'bamboo scaffolding', boka 'canoe', фanua 'village', utan 'cooking pot', yala 'road'.

Olson (n.d.) also records that Kola classifies several landscape features as ANIMATE: mah 'river', tabah 'rocky land', yak 'hill', lopuh 'kind of hole in the ground', and hafa 'water spring'. The examples in (23) illustrate this.
(23) a. $\frac{M a h}{\text { river }}$
$\begin{array}{ll}\underline{\text { nekin }} & \mathrm{ral}=\underline{n i} . \\ \text { THAT.AN } & \text { deep=3sG.AN }\end{array}$
'That river is deep.' (Olson n.d.)
b.
ne na
alral meter
dubam.
spring
THAT.AN 3SG.POSS
depth meter six
'That spring's depth is six meters.' (Olson n.d.)

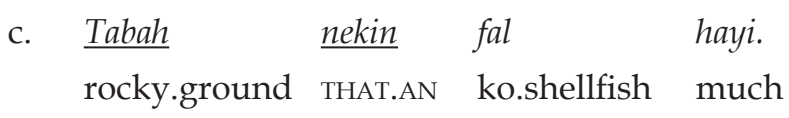
'That rocky ground (has) a lot of shellfish.' (Olson n.d.) 
De Winne (2013) finds that some nouns referring to units of time are classified ANIMATE, as with the nouns yam 'hour' and menit 'minute' in (24).

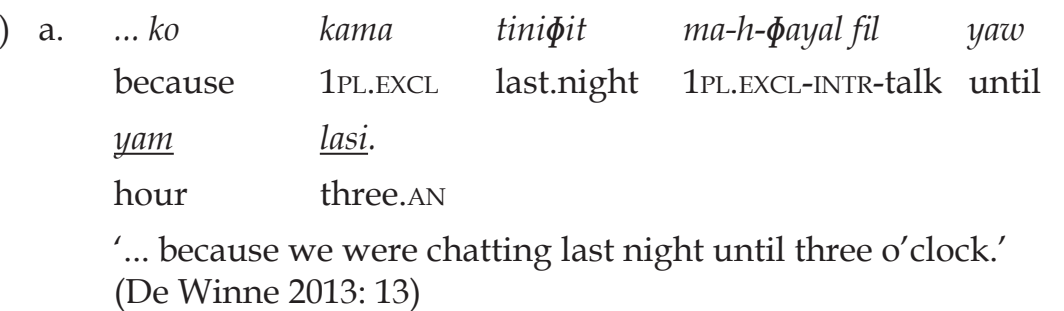

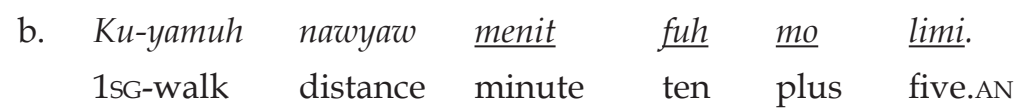
'I walked about fifteen minutes on foot.' (De Winne 2013: 14)

De Winne (2013) also observes that some of these appear to have variable gender classifications. For instance, compare the agreement of $\phi u l a n$ 'month/ moon' in (25). In (25a) dulan is ANIMATE as seen by the agreement on the numeral 'four', whereas in (25b) it is INANIMATE as seen by the agreement (or rather lack of agreement) on 'one'. The difference here appears to be that ANIMATE $\phi u l a n$ denotes a time duration as in the examples with yam and menit above, whereas INANIMATE $\phi$ ulan denotes a specific calendar month, in this instance, November.

\begin{tabular}{|c|c|c|c|c|c|c|c|c|}
\hline \multirow{2}{*}{\multicolumn{2}{|c|}{ (25) a. }} & $\begin{array}{l}\text { фalaw } \\
\text { house }\end{array}$ & $\begin{array}{l}e \\
\text { THAT.INAN }\end{array}$ & $\begin{array}{l}\text { a-min } \\
\text { 3sG-stay }\end{array}$ & $\begin{array}{l}e \\
\text { THAT.INAN }\end{array}$ & $\frac{\text { Фulan }}{\text { month }}$ & $\begin{array}{l}\frac{k a f i .}{\text { four.AI }} \\
\text { foul }\end{array}$ & \\
\hline & & \multicolumn{7}{|c|}{ 'That house has been there four months.' (De Winne 2013: 13) } \\
\hline & b. & Takan & $a-y u f$ & ban & $\Phi$ ulan & fuh & $\underline{m o}$ & $\underline{\text { ot }}$ \\
\hline & & usually & 3sG-blow & from & month & ten & plus & one \\
\hline
\end{tabular}

Plants and their parts have more labile gender classifications in Kola, with a part-whole distinction in reference determining whether the noun is treated as ANIMATE or INANIMATE. For instance, Olson (nd.) notes that ' [a] mango tree is [ANIMATE] but a piece of mango is [INANIMATE]'. In (26) wee 'mango' is treated as ANIMATE where reference is to the tree (whole) being in a state of flowering (26a), it is INANIMATE where reference is to the fruit (part) being sour (26b).

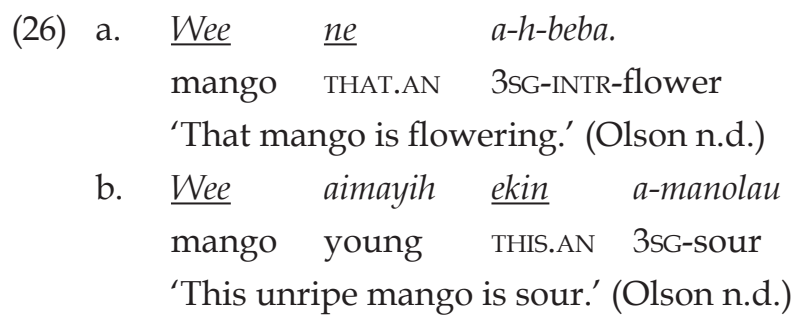


Similarly, the noun kai 'tree' can have variable classification depending on whether reference is to the part or the whole. In (27a) kai refers to the tree as a whole living organism and is classified ANIMATE. In (27b) kai refers to a portion of the tree which has dried out and fallen off and is classified INANIMATE.

$$
\begin{aligned}
& \text { a. Kai nekin ramau haf } \underline{\underline{n i}} \\
& \text { tree THIS.AN already ailing }=3 \mathrm{sg} \text {.AN } \\
& \text { 'That tree is already dead.' (Olson n.d.) } \\
& \text { b. Kai bodil ekin ramau a-фan. } \\
& \text { tree dry THIS.AN already 3sG-fall } \\
& \text { 'This dried (piece of) wood has already fallen.' (Olson n.d.) }
\end{aligned}
$$

\subsection{DOBEL}

Dobel [ISO 639-3: kvo] is spoken in central-eastern Aru, occupying the entire east coast of Kobror Island, as well as having smaller numbers of settlements inland on Kobror, on both sides of the Barakai Straits, and on Wokam island (Lewis et al. 2014). The language is strong and increasing in numbers of speakers, being even learnt by outsiders who live in Dobel villages. The data used in this sketch come from both published and unpublished data of Jock Hughes, a linguist with the Wycliffe organization who has worked for several decades on language issues and bible translation with the Dobel.

\subsection{LOCUS OF GENDER MARKING}

Subject verb agreement in Dobel involves active verb proclitics and stative verb enclitics. 3rd person forms are given in (28).

Dobel 3rd person verb agreement (Hughes 2000)

(28) a. Active verb proclitics

$$
\text { 3sG } \quad 2 a=\sim n a=3 \mathrm{PL} \quad d a=
$$

b. Stative verb enclitics

$$
\begin{aligned}
& \text { 3SG.AN }=n i \quad \text { 3PL } \quad=y e \sim=d i \\
& (\text { SSG.INAN V/_\#-i) }
\end{aligned}
$$

Similar to the systems we have already seen in Ujir and Kola, Dobel differentially marks nouns of ANIMATE-INANIMATE gender distinction on stative verbs. For instance, on soba 'good', ANIMATE tamatu 'person' agrees with the verb (29a), but INANIMATE $k^{w}$ alar 'house' does not (29b).

Dobel 3rd singular stative agreement

(29) a. ANIMATE subject

$$
\begin{array}{lll}
\text { Tamatu } & \text { ne } & s \sim \text { soba=ni. } \\
\text { person } & \text { DEM } & \text { RED good=3sG.AN }
\end{array}
$$

'That person is good.' (Hughes 2000: 139) 
b. INANIMATE subject

K walar ne s soba.

house DEM RED good

'That house is good.' (Hughes 2000: 139)

On a selection of disyllabic stative verbs, the second vowel (usually /a/) umlauts to /i/ with singular INANIMATE subjects. ${ }^{7}$ This is similar to the i-umlaut observed in Kola, but is distinct in picking out only INANIMATE nouns. Examples are presented in Table 4.

\begin{tabular}{|c|c|c|}
\hline & lo?ar 'good' & mayan 'sharp' \\
\hline $1 \mathrm{sG}$ & lopar $=\eta u$ & mayan=yu \\
\hline $2 \mathrm{sG}$ & lopar $=2 a$ & mayan $=? a$ \\
\hline 3SG.INAN & lopir & mayin \\
\hline 3SG.AN & lo?ar $=n i$ & mayan $=n i$ \\
\hline 1PL.INCL & lopar $=d a$ & mayan $=d a$ \\
\hline 1PL.EXCL & lo?ar $=$ ?ama & mayan=?ama \\
\hline $2 \mathrm{PL}$ & loPar $=$ ?ami & mayan=?ami \\
\hline 3PL & lopar=ye & majan=ye \\
\hline
\end{tabular}

Table 4. Dobel stative verbs showing i-umlaut in the 3rd person singular.

Dobel numerals also inflect to agree with the head noun of the NP in which they occur. Numeral inflection shows a three-way division in the 3rd person: HUMAN, ANIMATE, and INANIMATE. The agreement forms appearing on numerals are given in (30).

Dobel 3rd person numeral inflection (Hughes 2000)

(30) HUM $=y e$ AN ?ay=

When quantifying a noun with a human referent, the numeral is marked with the enclitic $=y e$, identical in form to the 3 rd person plural agreement form appearing on stative verbs (31a). When quantifying an ANIMATE noun with a non-human referent, the numeral is marked with the proclitic ?ay $=(31 b)$. Finally, when quantifying an INANIMATE noun, the numeral is unmarked (31c).

7 Jock Hughes (personal communication) notes that sometime instead of an i-umlaut he finds an u-umlaut in Dobel. For instance, sometimes one dialect has $<i>$ and another has $<\mathrm{u}>$ thus: rakwar 'bright, light' inflects rakwar=ni in all dialects, but $r a k w<u>r$ in the Koijabi dialect and $r a k w<i>r$ in Warjukur. 
Dobel numeral agreement (Hughes 2000: 139)

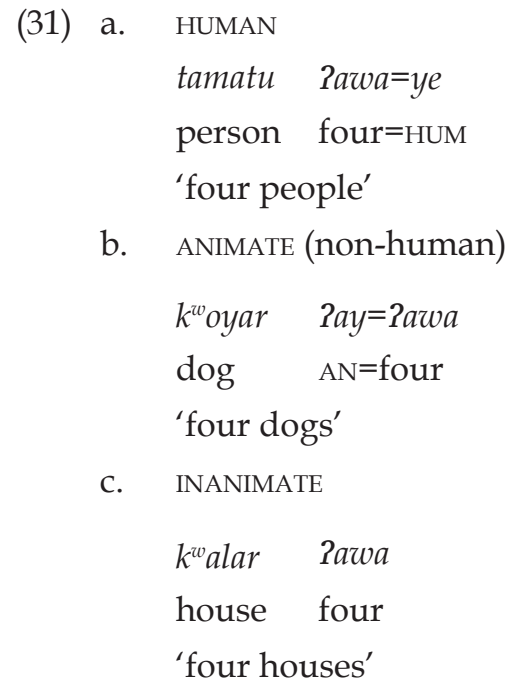

Unlike other Aru languages, Dobel demonstratives are not marked for the INANIMATE-ANIMATE distinction (contra Hughes 2000), but marks a mass-count distinction (Jock Hughes personal communication).

\subsubsection{SEMANTICS OF GENDER ASSIGNMENT}

The various publications of Jock Hughes make it clear that, as in the other languages in Aru, gender agreement in Dobel is a matter of lexico-grammatical rather than semantic classification of animates and inanimates. The examples in (32) show ANIMATE nouns with inanimate referents indexed by the ANIMATE agreement marker $=n i$. The examples in (33) show nouns with inanimate referents and whose INANIMATE classification is apparent from the lack of an agreement marker on the verb.

Examples of Dobel ANIMATE nouns with inanimate referents

(32) a. yiram 'axe'

\begin{tabular}{|c|c|c|c|c|}
\hline$\underline{\text { Yiram }}$ & ne & $20 m=\underline{n i}$ & $2 a=\phi \sim \phi a n$ & re \\
\hline axe & REL & 1sG:CAUS=3SG.AN & $3 \mathrm{SG}=\mathrm{RED} \sim \mathrm{fall}$ & LOC \\
\hline $\begin{array}{l}\text { koytul=ni } \\
\operatorname{sink}=3 \text { sG.AN }\end{array}$ & $\begin{array}{l}\text { Pona'lay. } \\
\text { indeed }\end{array}$ & & & \\
\hline
\end{tabular}

'The axe, which I dropped the[re], did indeed sink.' (Hughes 2000: 177)

b. Padera 'chair'

$\underline{\text { Padera }}$ ne $m=t \sim$ talar $=\underline{n i} \quad$ mona $=\underline{n i}$.

chair REL 2sG=RED $\sim$ sit=3sG.AN old=3sG.AN

'The chair on which you are sitting is old.' (Hughes 2000: 177) 
Examples of Dobel INANIMATE nouns with inanimate referents

(33) a. ser'tay 'clothes'

?amu ser'tay maray.

2sG.POSs clothes dry

'Your clothes are dry.' (Hughes 2000: 172)

b. daba 'canoe'

Daba ne sayi.

canoe DEM.REL long

'That canoe is long.' (Hughes 2000: 170)

Hughes (n.d.) contains a list of 142 ANIMATE nouns with inanimate referents, allowing for the most comprehensive treatment of the semantic patterns in the ANIMATE classification of inanimates for any Aru language. Hughes (n.d.) observes that semantics plays a significant role in the classification of plant and animal parts: "[A]ll whole animate objects (humans, animals, and plants) are in the [ANIMATE] class. Some parts of animate objects are [INANIMATE] class, for example, the names of tree species are animate, but their fruits are inanimate, so: nor (animate) 'coconut tree' and nor (inanimate) 'coconut'". In addition, what we see is that the assignment of nouns referring to inanimates to the ANIMATE gender is not entirely random; ANIMATE nouns with inanimate referents are not typically semantically isolated instances within the ANIMATE gender, but rather cluster into sets with semantically similar members.

Dobel classifies certain landscape features as ANIMATE. The Dobel ANIMATE landscape nouns can be classified into two broad sets of items: (i) bodies of water occurring in nature and their movements (Table 5) and (ii) rocks, rock formations, and formations of built up earth (Table 6).

\begin{tabular}{|c|c|c|c|}
\hline taw & $\begin{array}{l}\text { 'pool formed by a river } \\
\text { flooding' }\end{array}$ & salin & $\begin{array}{l}\text { 'channel in a river or } \\
\text { estuary' }\end{array}$ \\
\hline soфul & $\begin{array}{l}\text { 'pool of sea-water which } \\
\text { is entirely sorrounded by } \\
\text { land' }\end{array}$ & $k^{w} a t u$ & $\begin{array}{l}\text { 'strait (sea channel } \\
\text { between island)' }\end{array}$ \\
\hline bal & 'pool caused by rainwater' & $k^{w} a l u r$ & 'deep water area of sea' \\
\hline yek $k^{w} a l$ & 'swamp' & 'фuwatu & 'ocean swell, roller' \\
\hline$k^{w}$ ar' $P o l$ & 'swamp' & $m a^{\prime}$ del & 'wave' \\
\hline ye?ay & 'gulf, bay' & yer & 'current (in sea or channel)' \\
\hline 'Po?atu & 'bay' & tay & 'tide' \\
\hline
\end{tabular}

Table 5. Dobel ANIMATE nouns referring to natural bodies of water and their movements (data from Hughes n.d.). 


\begin{tabular}{|c|c|c|c|}
\hline фatu & 'rock' & lisa & 'cave' \\
\hline dera'??ay & 'tiny pebble' & til & 'ridge' \\
\hline Pubu & 'stone (individual stones)' & neyam & 'rocky hill/mountain' \\
\hline tabar & 'rock (fixed mass)' & $\phi u ? a r$ & 'hill' \\
\hline ParPeram & 'sharp rock in the ground' & $k^{w}$ arisa & 'island' \\
\hline sodal & 'large rocks at sea' & Pow & 'island in a river' \\
\hline
\end{tabular}

Table 6. Dobel ANIMATE nouns referring to rocks, rock formations, and formations of built up earth (data from Hughes n.d.).

A small number of nouns referring to naturally occurring objects situated in the sky or air are ANIMATE. These are $k^{w} a y$ ' $\phi \phi e r^{\prime}$ Venus (the planet)', tak $k^{w} u n$ 'star', 2abuwa?an 'rainbow' and the semantically similar rakwar 'brightness, light', as well as ?aфal 'black cloud, tornado', baloyan 'storm cloud', and sabun 'steam'.

Many aspects of material culture receive ANIMATE classification. A large number of common items used in the garden and house are included in this set. Table 7 sets the ANIMATE nouns of this type from Hughes (n.d.).

\begin{tabular}{|c|c|c|c|}
\hline Pabil & 'tongs for eating sago' & man' 'ota & 'plate' \\
\hline 'Padi?u & 'sack' & nara & 'sago trough' \\
\hline Pilir & 'needle' & ya'wul & 'hammer' \\
\hline Pini?ir & 'file (tool)' & 'neta?u & 'chisel' \\
\hline PPira & 'floor mat' & yer'?ay & 'sago cake' \\
\hline Pobor & 'torch' & 'rinatu & $\begin{array}{l}\text { 'filter for removing pulp out } \\
\text { of sago starch' }\end{array}$ \\
\hline ddiфil & 'rattan whip' & ssayan & 'fan' \\
\hline ddobar & 'leaf plate' & tabay & $\begin{array}{l}\text { 'yoke, pole for carrying } \\
\text { things on shoulder' }\end{array}$ \\
\hline diyan & 'plate, dish' & talak $^{w}$ ala & 'shelf' \\
\hline фала & 'wide base of sago frond' & taya'loy & 'shoulder bag' \\
\hline$\phi \phi a k^{w} u r$ & 'stick of a trap, or a sago trough' & tila & 'staff, walking stick' \\
\hline$k^{w} a w$ & '(scrubbing) brush' & tola & 'scoop, water dipper' \\
\hline$k^{w}$ ureri & 'sieve' & ttayan & 'ring (on finger)' \\
\hline$k^{w} u^{\prime}$ ror & 'clay water pot' & tun & 'cooking stones, stove' \\
\hline layeyin & 'toothpick' & yadeyan & 'rattan mat' \\
\hline lla?ur & 'broom' & yel & 'comb' \\
\hline lloфi & 'flag' & yyon & 'dibble stick' \\
\hline lowan & $\begin{array}{l}\text { 'mortar (as in mortar and } \\
\text { pestle)' }\end{array}$ & & \\
\hline
\end{tabular}

Table 7. Dobel ANIMATE nouns referring to gardening and domestic items (data from Hughes n.d.). 
Prominent semantic subsets of ANIMATE nouns are boat parts and items used in hunting and fishing. Table 8 sets out the 21 ANIMATE boat part nouns and Table 9 the 15 ANIMATE hunting/fishing nouns from Hughes (n.d.).

\begin{tabular}{|c|c|c|c|}
\hline bbuwar & 'wheel in a pulley' & senaфara & 'outrigger cross pole' \\
\hline ddow & $\begin{array}{l}\text { 'stopper or plug (used to } \\
\text { plug a hole in a boat used } \\
\text { for letting water out)' }\end{array}$ & se?i & 'punting pole' \\
\hline фasan & $\begin{array}{l}\text { 'oar (used for rowing a } \\
\text { boat, not paddling it)' }\end{array}$ & si'?asi & $\begin{array}{l}\text { 'anchor (the kind that } \\
\text { hooks into the seabed)' }\end{array}$ \\
\hline фeri & $\begin{array}{l}\text { 'paddle (used for } \\
\text { paddling a boat)' }\end{array}$ & taba?ar & 'tiller, helm' \\
\hline$k^{w} u l i n$ & 'rudder (of boat)' & tak $k^{w} a l$ & 'mast (of boat)' \\
\hline liyan & 'mast (of a boat)' & toba & 'anchor (a heavy stone)' \\
\hline loba'tay & 'outrigger of canoe' & ya'bor & $\begin{array}{l}\text { 'wooden pole at stem } \\
\text { and stern of traditional } \\
\text { sailing boats, these extend } \\
\text { beyond the deck and are } \\
\text { decorated at the top' }\end{array}$ \\
\hline lolin & 'pulley, block' & yabukwan & 'pole in sea' \\
\hline 'malatu & $\begin{array}{l}\text { 'adze; main sheet on boat } \\
\text { (= the rope that pulls the } \\
\text { mainsail)' }\end{array}$ & yer'man & $\begin{array}{l}\text { 'wood which supports } \\
\text { float on outrigger' }\end{array}$ \\
\hline mona'nay & 'front pole of tripod mast' & wur'tan & $\begin{array}{l}\text { 'pole to hold lower part of } \\
\text { sail out on traditional Aru } \\
\text { sailing rig' }\end{array}$ \\
\hline seliфur & $\begin{array}{l}\text { 'sago thatch roof for a } \\
\text { canoe' }\end{array}$ & & \\
\hline
\end{tabular}

Table 8. Dobel ANIMATE nouns referring to parts of boat, canoe (data from Hughes n.d.).

\begin{tabular}{llll}
\hline Padasa & $\begin{array}{l}\text { 'arrow or spear made of } \\
\text { bamboo with barbs' }\end{array}$ & dder & $\begin{array}{l}\text { 'poker for drying bird of } \\
\text { paradise skins' }\end{array}$ \\
butal & 'spear' & Palinu & 'fishing line' \\
daфal & 'spear' & su'?e & 'fishing net for throwing' \\
'mina?u & 'gun' & ssur + & 'kind of shrimp net' \\
yina & 'small arrow made from & rrir $\ddagger$ & 'fishing net' \\
& dried sago leaf' & & \\
wurfedi & $\begin{array}{l}\text { 'sign left to indicate an } \\
\text { animal taken from a trap' }\end{array}$ & yar & 'fish trap' \\
& &
\end{tabular}




$\begin{array}{ll}\text { P2uli 'hide wall for hunting pigs' wusar } & \text { 'fish spear' } \\ \text { taman } & \text { 'tree house/hide (used for } \\ & \text { shooting birds from)' }\end{array}$

† Also means for 'spoon'

$\ddagger$ Also means for 'earthquake'

Table 9. Dobel ANIMATE nouns referring to items used in hunting, fishing (data from Hughes n.d.).

Smaller subsets of animate nouns given in Hughes (n.d.) are musical instruments (Table 10) and house parts (Table 11).

\begin{tabular}{ll}
\hline $\begin{array}{l}\text { bboyu } \\
\text { ddala }\end{array}$ & $\begin{array}{l}\text { kind of gong } \\
\text { kind of gong }\end{array}$ \\
yili & bell \\
நyula & flute \\
saramina & kind of gong \\
sitar & kind of skin drum \\
\hline
\end{tabular}

Table 10. Dobel ANIMATE nouns referring to instruments (data from Hughes n.d.).

\begin{tabular}{ll}
\hline $\begin{array}{l}\text { llayan } \\
\text { ribil }\end{array}$ & $\begin{array}{l}\text { beam (for example in a house) } \\
\text { door bolt (large wooden pole } \\
\text { across door) } \\
\text { wooden upright (in house } \\
\text { ctu?a }\end{array}$ \\
yay'tan & $\begin{array}{l}\text { construction) } \\
\text { yaya }\end{array}$ \\
\hline
\end{tabular}

Table 11. Dobel ANIMATE nouns referring to house parts (data from Hughes n.d.).

\section{DISCUSSION: NEUTER GENDER IN PROTO-ARU}

The three Aru languages discussed in this paper show easily discernable similarities in their agreement systems and in their assignment of nouns to genders. These can be seen to point back to grammaticalized neuter-gender distinction being present in their common ancestor, proto-Aru. In this section, I consider what the details presented from Ujir, Kola, and Dobel tell us about the proto-system of gender marking.

The agreement system of proto-Aru appears to have marked an ANIMATEINANIMATE gender distinction on stative verbs, but not on active verbs as is the case in all three modern languages considered here. In the singular, nouns of INANIMATE gender were unmarked on the verb, while ANIMATE ones were. Already in proto-Aru, there was a stative enclitic ${ }^{*}=n(i, a)$ marking 3 rd person ANIMATE singular. The 3rd person INANIMATE singular appears to be have originally not been entirely unmarked, but on some nouns was indexed in proto-Aru by means of an infix ${ }^{*}<i>$, such as is found fossilised in many roots in Dobel for INANIMATE 3rd person singular and in Kola for 3rd person singular of both genders. In the plural, nouns of INANIMATE gender were unmarked on the verb with ${ }^{*}=s(i, e)$ and ANIMATE ones with ${ }^{*}=d i$. This distinction is maintained in Ujir, but lost in Kola and Dobel. The different stative agreement forms in 
the 3rd person plural in Kola and Dobel, however, represent the remnants of the earlier ANIMATE-INANIMATE gender distinction in the plural.

On numerals, proto-Aru also marked gender. Numerals agreeing with INANIMATE nouns were unmarked, while those agreeing with ANIMATE gender were marked. The form of the marking is not entirely clear: Ujir and Dobel indicate that it had the form ${ }^{*}=s(i, e)$, while Kola suggests a form ${ }^{*}-i /<i>$. Dobel is unique in the Aru languages in having elaborated gender marking on numerals by innovating the morpheme ?ay= marking non-human ANIMATE nouns and restricting its reflex of $* s(i, e),=y e$, to nouns with human referents.

Proto-Aru demonstratives were marked for gender. A comparative analysis of the forms indicate that * $n$ - was used to mark ANIMATE gender on demonstratives, whilst its lack indicated INANIMATE gender. Again, Dobel is innovative having reinvented the ANIMATE-INANIMATE distinction as a masscount distinction in which originally ANIMATE forms mark count nouns and INANIMATE forms mass nouns.

Comparison of the three modern languages discussed here also gives some clues as to patterns of assignment to genders in the proto-language. Whilst many of the details of gender classifications vary from language to language, already in proto-Aru it appears that the ANIMATE gender included nouns referring to inanimates. This is suggested by the observation that certain inherited nouns referring to inanimates are consistently classed as ANIMATE across the modern languages. These include nouns such as reflexes of ProtoAustronesian *batu 'stone' and *ma-qalun 'wave, billow'. Variable assignment of nouns with plant referents to ANIMATE or INANIMATE depending on whether reference is to the part or the whole is also shared across the Aru languages and presumably goes back to proto-Aru. For other nouns, the modern varience in gender assignment reflects different classificatory tendencies in operation in individual languages post-dating the breakup of proto-Aru. For instance, Rick Nivens (personal communication) observes changes to classifications in the ANIMATE gender in West Taragan: "A lot of Malay loans are (or were) in the [ANIMATE] class, irrespective of their actual animacy. (It seems, though, that younger speakers have made a lot of the 'actually inanimate' ones grammatically [INANIMATE] too.)".

In short, Aru languages have systems of gender comparable to that uncovered by Hein Steinhauer in his pioneering work on Biak. This paper goes a small way to bringing to light some of the characteristics of Aru gender systems. 


$\begin{array}{ll}\text { ABBREVIATIONS USED } \\ 1 & : \text { first person } \\ 2 & : \text { second person } \\ 3 & : \text { third person } \\ \text { AN } & : \text { animate } \\ \text { C } & : \text { consonant } \\ \text { CAUS } & : \text { causative } \\ \text { CLF } & : \text { clasifier } \\ \text { CMP } & : \text { Central Malayo-Polynesian } \\ \text { DEM } & : \text { demonstrative } \\ \text { EXCL } & : \text { exclusive } \\ \text { FUT } & : \text { future } \\ \text { HUM } & : \text { human } \\ \text { INAN } & : \text { inanimate } \\ \text { INCL } & : \text { inclusive } \\ \text { INDEF } & : \text { indefinite } \\ \text { INTR } & : \text { intransitive } \\ \text { LOC } & : \text { locative } \\ \text { NP } & : \text { noun phrase } \\ \text { NUM } & : \text { numeral } \\ \text { POSS } & : \text { possessive } \\ \text { PL } & : \text { plural } \\ \text { RED } & : \text { reduplication } \\ \text { REL } & : \text { relative } \\ \text { SG } & : \text { singular } \\ \text { V } & : \text { vowel } \\ & \end{array}$

\section{REFERENCES}

Blust, Robert. 1993. "Central and Central-Eastern Malayo-Polynesian”, Oceanic Linguistics 32: 241-93.

Blust, Robert. 2009. The Austronesian languages. Canberra: Research School of Pacific and Asian Studies, Australian National University. [Pacific Linguistics 602.]

Blust, Robert. 2014. “Dobel Historical Phonology”, Oceanic Linguistics 53/1: 37-60.

Bolton, Rosemary. 1990. “A preliminary description of Nuaulu phonology and grammar". MA thesis, University of Texas, Arlington.

Collins, James T. 1982. "Linguistic research in Maluku; A report of recent fieldwork", Oceanic Linguistics 21: 73-146.

Dalrymple, Mary and Suriel Mofu. 2012. Dusner. München: Lincom Europa. 
Donohue, Mark and Charles E. Grimes. 2008. "Yet more on the position of the languages of eastern Indonesia and East Timor", Oceanic Linguistics 47: 114-58.

Gasser, Emily. 2015. Windesi Wamesa Morphophonology. PhD thesis, Yale University.

Greenberg, Joseph H. 1963. "Some universals of grammar with particular reference to the order of meaningful elements", in: Joseph H. Greenberg (ed.), Universals of Human Language, pp. 73-113. Cambridge, Mass: MIT Press.

Heuvel, Wilco van. 2006. Biak, description of an Austronesian language of Papua. Utrecht: LOT.

Hughes, Jock. 1987. “The languages of the Kei, Tanimbar, and Aru archipelagos of the South-East Moluccas; A preliminary lexicostatistic classification", NUSA, Linguistic Studies of Indonesian and Other Languages in Indonesia 27: 71-111.

Hughes, Jock. 1995. "Dobel (Aru Islands); Introduction and wordlist”, in: Darrell T. Tryon (ed.), Comparative Austronesian dictionary; An introduction to Austronesian studies, Part 1, pp. 637-50. Berlin/New York: Mouton de Gruyter.

Hughes, Jock. 2000. "The morphology of Dobel, Aru with special reference to reduplication", in: Charles E. Grimes (ed.), Spices from the East, pp. 131180. Canberra: Research School of Pacific and Asian Studies, Australian National University. [Pacific Linguistics 503.]

Hughes, Jock. n.d. "List of Dobel animate nouns that refer to inanimate objects". [Unpublished manuscript.]

Hughes, Jock and Katy Hughes. 1989. "A phonology of Dobel”, Workpapers in Indonesian Languages and Cultures 7: 43-76.

Lewis, M. Paul, Gary F. Simons, and Charles D. Fennig (eds). 2014. Ethnologue; Languages of the World. Seventeenth edition. Dallas, Texas: SIL International. [Online version: http:/ / www.ethnologue.com.]

Nivens, Richard. 1992. "A lexical phonology of West Tarangan", in: Donald A. Burquest and Wyn D. Laidig (eds), Phonological studies in four languages of Maluku, pp. 127-227. Dallas, Texas: SIL International.

Nivens, Richard. 1993. "Reduplication in four dialects of West Tarangan", Oceanic Linguistics 32: 353-387.

Nivens, Richard. 2002. Borrowing versus code-switching in West Tarangan (Indonesia). Dallas, Texas: SIL International. [Publications in Sociolinguistics 8.]

Olson, Richard. n.d. "Dictionary of Kola". [Unpublished Toolbox files.]

Plank, Frans and Wolfgang Schellinger. 1997. "The Uneven Distribution of Genders over Numbers; Greenberg Nos. 37 and 45", Linguistic Typology 1: 53-101.

Schapper, Antoinette. 2010. "Neuter gender in eastern Indonesia", Oceanic Linguistics 49/2: 407-435.

Schapper, Antoinette. 2011. "Phalanger facts; Notes on Blust's marsupial reconstructions", Oceanic Linguistics 50/1: 154-168. 
Steinhauer, Hein. 1985. "Number in Biak; Counterevidence to two alleged language universals", Bijdragen tot de Taal-, Land-en Volkenkunde 141: 462-485.

Takata, Yuko. 1992. "Word structure and reduplication in Kola”, NUSA, Linguistic Studies of Indonesian and Other Languages in Indonesia 34: 47-68. [Series Descriptive studies in languages of Maluku (Donald A. Burquest and Wyn D. Laidig eds.), Dallas, Texas: SIL International.]

Takata, Masahiro and Yuko Takata. 1991. Dahlang dal Kola relih = Percakapan dalam Bahasa Kola = Kola conversations. Ambon: Universitas Pattimura and Summer Institute of Linguistics.

Takata, Masahiro and Yuko Takata. 1992a. "Kola phonology", NUSA, Linguistic Studies of Indonesian and Other Languages in Indonesia 34: 31-46.

Takata, Masahiro and Yuko Takata. 1992b. "Word structure and reduplication", NUSA, Linguistic Studies of Indonesian and Other Languages in Indonesia 34: 47-68.

Winne, David de. 2013. "A morpho-syntactic sketch of Kola". MA thesis, Leiden University. 